\title{
SYMBOLIC MEANING OF BASAHA ISIFU RITUALS: THE TRADITION OF MUNA SOCIETY PRIOR TO NISFU SYA'BAN NIGHT IN MUNA REGENCY
}

\author{
Rahmat Sewa Suraya \\ Department of Oral Traditions, Faculty of Humanities, Halu Oleo University, \\ Jl. H.E.A. Mokodompit, Kota Kendari Sulawesi Tenggara \\ Email:mhat_suraya@yahoo.co.id \\ Wa Ode Siti Hafsah \\ Department of Anthropology, Faculty of Cultural Sciences Halu Oleo University, \\ Jl. H.E.A. Mokodompit, Kota Kendari Sulawesi Tenggara \\ Email: sittihafsahwaode@gmail.com \\ La Niampe \\ Department of Oral Traditions, Faculty of Humanities, Halu Oleo Unive rsity, \\ Jl. H.E.A. Mokodompit, Kota Kendari Sulawesi Tenggara \\ Email: Iniampe66@gmail.com \\ Heniman \\ Department of Oral Traditions, Faculty of Humanities, Halu Oleo University, \\ Jl. H.E.A. Mokodompit, Kota Kendari Sulawesi Tenggara \\ Email: bungheniman321@gmail.com.
}

Article received March 13th, 2021; Article revised April 23th, 2021; Article approved May 8th, 2021

\begin{abstract}
During Nisfu shay'ban night in Muna community, various good practices are performed. These practices aim to achieve the primacy of the Nisfushay'ban night which usually starts after the evening prayer by reciting Yasin for three times and ends it with prayer. To welcome the night of Nisfu shay'ban, Muna community performed a ritual called "the Basaha Isifu". The purposes of this study are (1) to find out the process of conducting the Basaha Isifu tradition in the community of KosundanoSub-district, (2) to understand the symbolic meanings of Basaha Isifu tradition. The location of this research was in Kosundano Subdistrict of Muna community. The data was collected through observation, interviews and documentation. The informants were selected using purposive sampling technique. The data analysis employed a qualitative descriptive analysis which includes data reduction, display data, and conclusion. The results of this study indicates that the implementation of Basaha Isifu tradition starts from (1) the preparation of all stuff needed for the ritual, (2) the implementation indicated by the prayer recitation, and (3) the closure indicated by the attendants shaking hands and enjoying dishes together. Symbolically, Basaha Isifu carried out by Muna community can be interpreted as a form of gratitude for the blessing of Allah SWT for wealth, longevity, health, and safety of all dangers.
\end{abstract}

Keywords: tradition, ritual, nisfu sya'ban, basaha isifu rituals.

\section{INTRODUCTION}

The term culture is stated by Koentjaraningrat as the whole results of human's mind and work. In other words, culture refers to anything that has been produced by human's thoughts and works (Sudibyo, et al 2013: 29).

According to Sibarani (2012: 120), oral tradition is a legacy that contains meaning, values, functions and cultural norms as well as parts of the past, present understandings and a view of the future.

The culture of each region gives birth to traditions as a manifestation of the owner's instincts (Muslim et.al., 2019). These traditions are used to understand the environment and guide people's behavior (Muslim, 2016: 109-122). The cultural 
diversity of the Indonesian people has grown and developed since thousands of years ago. This is none other than the legacy of the ancestors of the Indonesian nation which is still carried out by the Indonesian people and has always colored people's lives today (Sumaatmaja 1998: 1). This cultural diversity is a form of ancestral wealth that is deliberately passed on and preserved for future generations.

In addition, Pudentia and Efendi (1996: 10) suggest that the oral tradition and arts in various situations can experience so rapid changes that they might be on the verge of extinction and no longer able to be easily recognized since.

Traditions adopted by society have various meanings (Asad et.al, 2012). The diversity of meanings contained in each community tradition has been used as a guide for life, so that society upholds the important values contained therein (Muslim, 2016: 221230). This is due to the influence of religion in human life even though religion and culture cannot be united but they are related to one another (Muslim, 2016: 259-274). Religion influences belief systems and life practices. On the other hand, culture can influence religion, especially in terms of how religion is interpreted in the rituals of a society (Subair, 2017: 198-213).

In some areas, communities carry out the celebration of the month of Sha'ban, such as the people of Bulus Hamlet, Pakem District, Sleman Yogyakarta where they conduct Ruwahan. It is a tradition of reciting prayers for the spirits of ancestors before the arrival of the holy month of Rahmadhan which is held in the month of Ruwah (Javanese calendar) or month of Sha'ban (Hijriah) (Roni, 2018).

Basaha Isifu in Muna society particularly at Kosundao Village community is conducted in Sha'ban, which this month the 8th month in the calendar Hijri or Islamic calendar. In essence, Basaha Isifu is a social activity involving the local community in a joint effort to celebrate the night of nis'fu Sha'ban. This is a variety of knowledge and customs passed orally from generation-generation (Hoed, 2008: 148),

In today's era, the tradition of Haroa is still practiced by the Muna community even though some people consider this tradition to be very contrary to the teachings of Islam because it is considered old-fashioned and made-up or bid'ah. However, the supporting community thinks that Haroa in religious life has a number of functions and meanings that are highly respected, especially in the realm of social, cultural and life religious, (Suraya 2014)

La Dhiri 57 (Imam Masjid AlMohajirin of Kosundano) said that if we ask Allah SWT for safety, fortune, longevity or other things during the implementation of Basaha Isifu, they will definitely be granted. This is due to the change of good and bad charity books for humans during Basaha Isifu. In addition, Basaha Isifu hospitality is also a medium for family, social, cultural and religious interaction. This can be seen from the enthusiasm of the community in participating in each implementation process.

Basaha Isifu in the people of Kosundano Village is carried out in the month of Sha'ban or before the month of Ramadan. For the time of practice, it is carried out on the twelfth night, the thirteenth night, the fourteenth, the fifteenth, until the sixteenth night. However, a small part of the community does it on the seventeenth night. Basaha Isifu can only be carried out by village elders or traditional leaders who are considered the center of policy making, La Maini (57).

Basaha Isifu is also carried out to honor their ancestral heritage. Even though it is currently in the modern era, the people Kosundao Village remain attached to Kosundao Village. This is due to their belief that this tradition will bring blessings and safety in the future.

However, to this day the Muna people, especially the young generation, is not aware of the symbolic meanings and the series of implementation of Basaha Isifu. The researcher once asked a teenager "Why don't you take part during the implementation of Basaha Isifu?"

He said, "Haroa is haram, it is not in accordance with Islamic teachings. In Islam preparing offerings is tantamount to associating Allah SWT with giving offerings to spirits. If this continues without repenting, Hell is guaranteed".

Based on the description above, the researchers were interested in studying Basaha Isifu in Kosundano Village, Parigi District, 
Muna Regency. For this reason, the researcher also conducted research as entitled "The Symbolic Meaning of Basaha Isifu Ritual: The Traditions of the Muna Community Prior to the Night of NisfuSya'ban in Muna Regency.

\section{RESEARCH METHOD}

This research used descriptive qualitative research methods. According to Bogdan and Taylor (Moleong, 2014: 4) qualitative methodology is a procedure of research that produces descriptive data in the form of written or spoken words from people and observable behavior.

By using qualitative descriptive, research analysis can be presented by providing a thorough and detailed description of the information obtained by researchers relating to the subject matter. It is because the main objective is to understand the social phenomena that exist in the environment, this research is a basic research. This research was conducted in Kosundano Village, Parigi District, Muna Regency. The location selection was made with the consideration that Basaha Isifu is still routinely carried out by local community leaders. The data were collected through observation, interview, and documentation. Observation is a method used by researchers to obtain data using systematic planning of the phenomena to be surveyed. Interview is a way of collecting data through structured oral communication activities. Documentation is a way of obtaining data in the field by capturing it through photos and videos, as well as sound recordings.

This study used a qualitative descriptive analysis. The analysis process is intended to organize and sort data into patterns, categories and a description so that a finding or conclusion is produced in line with the research objectives. Stages in this analysis are data reduction, data display, and conclusion. Data reduction was done to data that are not relevant to the issues. Data display is displaying reduced data in an organized way and easy to understand. Conclusion is drawing inferences from existing evidence. The conclusions generated in this study are directed to answer all research problems and provide an overview of the process and symbolic meaning of Basaha Isifu.
This research used semiotic theory where this theory consists of a set of theories about how signs represent objects, ideas, circumstances, situations, feelings, conditions outside of the signs themselves (Little, 2009: 53). Peirce also explained that semiosis is a sign or representamen is something that for someone represents something else in some way or capacity. Something else is called an interpretant of the first sign which in turn refers to the object, (Budiman, 2011: 17)

\section{DISCUSSION}

Etymologically Basaha Isifu consists of two syllables, namely Basa and Isifu. Basa comes from the Muna language which means read. $H a$ here is an affix which indicates that Basa done repeatedly, while Isifu or Nis'fu comes from Arabic which means middle, La Jhiri (57) Imam Masjid Al-Mohajirin. So Basaha Isifu is a tradition of praying to Allah SWT, whether it is asking for safety, good fortune, longevity, and safety of all dangers that is carried out in the middle of the month of Sha'ban.

Basaha Isifu is a routine for the people of Kosundano Village every year, namely in the middle of the month of Sha'ban. The month of Shaban is the eighth month on the Hijri calendar which is flanked by the month of Rajab and the month of Ramadan. As stated by La Jhiri (57) Imam of the Masjid AlMohajirin, Kosundano Village, he said that if we ask Allah SWT for safety, good fortune, longevity or other things during the implementation of Basaha Isifu, it will definitely be granted. This is due to the change of good and bad charity books for humans. In this study, there are major sub-topics, namely the process of executing and its symbolic meaning in its implementation.

\section{The Process of Implementing Basaha Isifu}

In the process of implementing Basaha Isifu, several things must be prepared to support the implement ation of Basaha Isifu. This preparation was deliberately carried out so that there were no mistakes during the implementation of Basaha Isifu. One of the organizers of the tradition, Basaha Isifu Mr. La Maini (57), has understood this because if there is a mistake it will change the value of Basaha Isifu itself. As stated by La Maini (57) as the organizer of Basaha Isifu, he said that: 
"Bha-bhaanodeghondodekialo is katokanoharoa, katubharinookuraani, pitaraa, kantalea, bheoenoIsifu".

Translation:

"First determine the night then the completeness of Haroa, additionally Al-Quran, Pitaraa (shown in the picture) lights (lights), and water for Isifu". (Interview on 15 May 2019).

Preparation in the process of implementing Basaha Isifu is really important that mistakes do not occur that it will not reduce the meaning in it. To further understand the preparation and implementation process, the explanation can be described as follows:

(a) Preparation Stage,

At this preparation stage there are two main points, namely: time, implementation of Basaha Isifu depending on the readiness of the organizer, namely on the twelfth night, the thirteenth night, the fourteenth night, the fifteenth night to the sixteenth night. There are even those who perform it on the seventeenth night, but it is very rarely carried out. The process of implementing Basaha Isifu was carried out at night from $17.30-23.00$ WITA, La Maini (57). Tools and materials needed in the process of implementing Basaha Isifu are described as follows:

(1) Katokano Haroa (completeness of Harao). Haroa is one of the conditions for carrying out Basaha Isifu. Haroa generally applies in carrying out traditions related to Islamic teachings. In Haroa, there are a number of traditional foods that are arranged in such a way based on the provisions set by the predecessor generation. The food in haroa is in the form of Sanggara (fried banana), Susuru (bowsprit), GhunteliKatoofi (boiled egg), okue (cake), Sirikaea (made from local chicken eggs mixed with sugar then boiled), Kalei Kataha (ripe banana), Manu Kaparende (chicken cooked using tamarind), Manu Kawei, glutinous rice with fried eggs on top. As stated by La Maini (57) that:

\footnotetext{
"Ani neangkainoharoa raise, kasukaradadibhekasukara mate. Kasukara Dadi plays pedaokatoba, okakawi, okaria, debasaneradhabu, isifu, nepoashabheneroraeaha. Anihanokasukara mate pedadebasaghomatenomaitu, notanda nematehano (kaerehano), pataino, etoluno, patainoifitu, ifituno (kabhotu), kafongkoranodhumaa until fitudhumaa. Dadi sadheanaghabheharoano."
}

\section{Translation:}

"Things related to Haroa are life and death. Life events are such as making someone turn into Muslim, marriage, seclusion, recitation Haroa in the month of Rajab, Nis'fu Sha'ban, Fasting Month, and Eid al-Fitr and Eid al-Adha as well. Death event is like sending a prayer to the deceased starting from the first day of death, before the three days, the three days, before the seven days, the seven days (release), the determination of the recitation of prayers on Friday nights is up to seven times. Each of those events always requires haroa".

Lack of understanding of the values contained in Haroa will be a definite answer to this problem, namely the influence of the modern era development in this 4.0 area. This can be seen from the young people in the community of Kosundano Village who mostly have gadget as a means of communication. Judging from its function, it is very useful in terms of information, be it in terms of education, art, religion and culture. The negative impact is that these young people are more obsessed with technology without seeing the point of view of local culture. It can be ascertained that if such a situation goes on, the tradition will definitely disappear by itself. For this reason, in order to preserve the tradition that has been passed on to the people of Kosundano Village, young people must be given a deeper understanding of the real meaning in the process of Haroa both using life events and death events.

(2) Al-Quran, Al-Quran is also one of the necessary things for carrying out Basaha Isifu. This Al-Quran is read by an employee of sara (Imamu) when Basaha Isifu takes place. The Al-Quran provided during the implementation of Basaha Isifu can be small or large, following to the preference of Sara's employees (Imamu). In the implementation of Basaha Isifu, the Al-Quran is used as an introduction or a link between humans and Allah SWT and a social link between one human and others. This is also explained in Surah Al-Imran verse 112, meanings:

"They are covered with humiliation wherever they are, unless they hold on to the rope (Religion) of Allah and the covenant with humans, and again, they get the wrath of Allah and they include humility. That is because they disbelieve in the verses of Allah and kill the Prophets without the right reason, thus they are disobedient and transgress". This is based on a fundamental belief by the people 
of Kosundano Village based on revelations from Allah SWT that have been sent to His Apostles. This understanding can be felt today because it continues to be conveyed by the Muumin people, one of which is the implementation of Basaha Isifu.

(3). Plain water for Sara's Servants. This drinking water was deliberately prepared by the organizer to be drunk by the sara employees (imammu) in order to maintain their solemnity in carrying Basaha Isifu. At the time of implementation Basaha Isifu, the guide must be in a state of khusyu in hopes to the Almighty God. The presentation must be adjusted to the social strata as an employee of Sara. There is a plate placed under the water glass. In the muna language, this plate is called Sangko, La Ndaadi (60).

It can be said that the people of Kosundano Village have great respect for sara employees when carrying out their duties, Mojhi, Khatibi, or Imamu. These are done as a form of gratitude to pray for the family (organizer) and the people of Kosundano Village to always be protected, hopefully a good luck, long life, safety, and avoid all kinds of reinforcements.

(4) Kampanaha. it is in the form of an amount of money that is kept on a plate and then covered with a cloth, as explained by Mr. La Maini (57) that:

\footnotetext{
"Kampanahamaituwelaloodoi. Doi welo campaign, maitudopototoanebheadhatinowuto,

bhahiokaomu, owalaka, bhemaradika. At that dolapisiane kai. Nopohala is Kalupino Kaino Kasukara Dadi BheKasukara Mate Anoa. Ani kasukaradadidomaianewepandanopiri, anekasukara mate domaianetewawonopiri”,
}

Translation:

"Kampanaha has money in it. Money in Kampanaha is adjusted to its own customs, be it is for the Kaomu, Walaka and Maradika groups. After that, the kampanaha is lined with cloth. In contrast, the folds are the fabric of life and death. If the show is on the cloth is from under the plate and the cloth is off from the plate.

This will be prepared by the organizers to be taken by Sara's employees. Kampanaha is taken at the completion of the procession of greetings.

It can be said that Kampanahaallotted is one of the requirements for carrying out Basaha Isifu in which there is an amount of money in it. This Kampanaha is also a sense of gratitude for the family (organizer) to
Sarah's employees who have guided the course of Basaha Isifu. For the placement of money in Kampanaha, rules have been made by the previous generation, which are adjusted to the social strata of the organizing family, be it Kaomu, Walaka or Maradika.

(5) Incense. This is one of the requirements in carrying out the Basaha Isifu tradition. In carrying out the tradition, both sukaradadi (life event) and sukara mate (death event) incense are always encountered. This indicates that burning incense is something important before doing Basaha Isifu Haroa.

This incense burner can use a plate, some even use ceramic made of clay with a shape like a bowl. There are three types of incense sticks that are used during the implementation of Basaha Isifu; skin, sugar, and the original incense, La Jhiri (57) Imam Masjid Al-Mohajirin.

It can be said that incense is something important in religious ceremonies in the community of Kosundano. Judging from the type, there are three types of incense that are always used in every religious ceremony, namely in the form of sugar, olive skin, and original incense.

(6). Pitaraa, it is also one of the necessities for carrying out Basaha Isifu. Pitaraa is rice which is stored in a plate with an egg on top. This was intended for all people present at that time to give alms according to their abilities.

In the Muna community, especially the people of Kosundano Village, before the holiday, they are required to pay zakat. In the Muna language, it is called Pundu Pitaraa. This was done to Sara's employees and then handed over to the poor. In carrying out Pundu Pitaraa, Sara's employees provide two choices: corn and rice with the determined price.

However, in the Basaha Isifu tradition, the community who performs Pundu Pitaraa is handled by the organizers of Bahasa Isifu traditon. The implementation process is also different. In Basaha Isifu, people personally put their money in a container that has been prepared according to their respective abilities.

(7), Penerang (Lamp), it is the main thing in carrying out Basaha Isifu. The light here is in the form of can lamps, flashlights, and others. This was deliberately prepared to 
anticipate that when carrying out this tradition, the electric lights went out, especially when Sarah's employees were reading the Koran. This action is a tribute to Basaha Isifu as a night to change the practice book of human actions. This month of Sha'ban is a month full of grace as previously conveyed by the informant that if we ask Allah SWT for safety, fort une, long life or other things during the implementation of Basaha Isifu, it will definitely be granted. This is due to the change of good and bad charity logbooks for humans (La Dhiri 57 Imam Masjid Al-Mohajirin, Kosundano Village). Selin is also to maintain the specialty of Sara's employees in carrying out their duties.

\section{Implementation}

The implementation stage is the core of a series of activities in Basaha Isifu. This is a form of gratitude for the blessings that Allah SWT has given to us all. At this stage of implementation, the community has gathered in the house that organizes Basaha Isifu, taking along their parents and children.

In this implementation process, all preparations have been completed according to the rules set by the predecessor generation. This provision cannot be changed because it will cause a shift in values in the process of implementing Basaha Isifu, La Jhiri (57) Imam of the Mosque Al-Mohajirin.

From the explanation above, it can be concluded that all the provisions that have been passed on by the previous generation are things that must be maintained in their application. This is recognized as a form of mutual respect by prioritizing Islamic teachings.

The stages of implementing Basaha Isifu can be described as follows:

(1). Incense Burning. The first thing in the implementation of Basaha Isifu, Burning incense is not only carried out in Islam but there are also other religions such as Hinduism that burn incense such as in Ngaben, ceremonies Religious ceremonies and others, La Jhiri (57)

$\mathrm{He}$ also added that in Islam itself there are hadiths that explain the use of Incense, which means:

"When Ibn Umar performs istijmar (burns incense) he resting with Ulawah without any mixture, and with kafur mixed with Ulawah. Then Ibn Umar continued, this is how Rasulullah SAW did istijmar. (Narrated by Nasa'i).

Incense was burned by Sara's own employees. After the burn was finished, Sara's employees put their hands on the incense which had already emitted smoke and then wiped it over. After that, it was handed over to the next host, and then passed on to all the people present at that time to have the the fragrant smell of the incense. (Sumer: documentation of the implementation of Basaha Isifu) From this explanation it can be concluded that the use of incense is not only found in Islam, but there are also other religions that use it such as Hinduism. In Islam itself, the use of incense is carried out during Basaha Isifu, particularly, in the people of Kosundano Village.

(2). Reciting the Holy Quran Verses, Reciting the Holy Quran is the second stage in the process of implementing Basaha Isifu. The letter recited is Surah Yasin. Before reading Surah Yasin, Sarah's employees first gave advice to all people who were present at that time. The advice is as follows:

"Aitu noratomo, this is
wulanoisifudadihanomodamotorolalo,
neatinemelahanosio-
siomoregionoompunafowaaghoradhaki,
informing bhenamekakodohobalaa. Then the people
who were present at that time answered with the word
umbee.

Translation:

\begin{abstract}
"Now comes the month of Nis'fu (the middle of the month of Shaban) so we calm our hearts, minds, intentions on righteous things. Hopefully Allah SWT will give you good luck, long life, and keep us from all calamity or danger." (The words were taken during the process of implementing Basaha Isifu).
\end{abstract}

The reading of Surah Yasin in the tradition of Basaha Isifu is carried out three times in succession. In every recitation of Surah Yasin in the last verses, the sara employee (imam) raises his hand upward after a period of time, the sara employee puts his hands down, this is done three times in succession.

(3) The recitation of Haroa (Debasa Haroa). Haroa is a number of foods stored in a tray. The food is served in dula which is usually covered with banana leaves before placing a variety of specialties made by the host. Dula as a place to put some food which is always covered with a white cloth. When 
the sara employee will start the recitation of Haroa, first hold the Haroa after that, giving advice to all who are present at that time. It is as follow:

"Aituinianoratomotorawulanoisifua.
Datumolanekawasanoompuasio-
siomokabhariainiadapoghawa-
ghawatoraatawanatitubhari.
Welotolantoomu nafowaaghokaghosa, oradhaki,
kasalamatibheumurumewanta.
Dadihanomodamekantalea ne lalo, damekantalea ne
neati, damokalalesawubhanoranda, dapohara-
haragamibheManusiaBhainto, naokesa ne fekiri,
naeta ne pogau, riosiomo
$\begin{aligned} & \text { Kawasanoompunafoseiseghoweloimani r be } \\ & \text { dhalametaano, " }\end{aligned}$

Translation:

"It has come again. So now the month of Syaban is here. We ask Allah SWT for this many, hopefully we will meet again or will increase. In this intention we will be given strength, good fortune, safety and longevity So we have to clean in our hearts, we clean our intentions, broaden our hearts, respect each other, good prejudice, speak politely, hopefully Allah SWT will unite us in faith and the right path".

Then the sara employee will start with the reading of the Shahada and istighfar which is then continued with the recitation of the Koran which is usually Surah Yasin, then continued with reading Tasbih, Tahmid, Tahlil, and Takbir which are usually read 99 times each. Then proceed with reading short letters. After finishing reading Haroa, Sara's employee returned to hold Haroa and continued with a greeting of La Jahri (57) Imam of the Al-Mohajirin Mosque.

(4) Greetings, a sign that the recitation of Haroa has been completed, starting from the host, their children and the people who were present at that time. In almost all community activities in Kosundano village, when meeting a person, known or unknown, it is always preceded by a greeting (handshake). This happens because the manifestation of the implementation process of tradition Hasaha Haroa (La Dhiri (57) (an interview on May 24, 2019).

(5) Employee of Sara had the Isifu water. Isifu water is plain water or water that is prepared in a container when carrying out Basaha Isifu. It was called Isifu water because it was intended when carrying out Basaha Isifu. As explained by La Dhiri (57) the Imam of the Al-Mohajirin Mosque in Kosundano Village he said:

\footnotetext{
"oenoisifumait uoengkalamata,

dadidoniatianedofoangkenemetahanokah,
}

nemodaihanokahnelatenewuto.

Ooemaituumatinokawasano Ompu, nodadi nokopongke, nokomatapedaduaintaidi. Dhadi ani doniatianemetahanonetaa, nembalikaago. Ani doniatianemodaiahonembalipanaki.

Dadihanomokomesoba-soba ghondokowutonoomputo this"

Translation:

"Isifu water is raw water, so it is intended to lead to good things, bad things depending on the will. Water is the people of Allah SWT., he is alive and has ears, has eyes, just like us. So, if we intend on good things it becomes medicine, if we intend on negative things then it becomes disease. So do not try to Allah SWT himself who sees us". (Interview on 24 May 2019).

This shows that the people of Kosundano Village believe that the water that is intended during the process of implementing Basaha Isifu can provide positive things for those who use it. They do this based on virtue in the middle of the month of Sha'ban which if they ask for mercy from Allah SWT, they will definitely be granted.

(6) Eating together, it has become commonplace in Muna society after carrying out the tradition of Basaha. This procession signifies the completion of a series of events. In haroa, much food was returned to the kitchen, then arranged and served again with other foods at Basaha Isifu. (Source: documentation of the implementation of Basaha Isifu.) In this process women play an important role in managing good food in the kitchen, while the men carry the food that has been prepared to be brought to the place where the tradition is held. In regulating food, it is not done just like that, but there are important things that must be considered, as follows:

1. The woman in charge of arranging food in the kitchen asks the total number of people sitting in the place of the implementation process to the woman who is in charge of serving food at the place where Basaha Isifu is implemented.

2. The woman in charge of the kitchen asked the number of aristocrats present at that time.

This was deliberately done to avoid mistakes in the process of serving food. This is the responsibility of the woman who works in the kitchen as food organizer, Wa Haniira (50).

After that the food that has been prepared is then picked up by the men and given to the women who managing the food. 
In this process, the food that is served for the first time is aimed at kao group, kaomu then followed by the groups below, namely walaka and maradika.

\section{The Meaning of the Symbolic in Basaha Isifu Tradition}

In order to understand the Pierce's view which is very complicated, for it is divided into three parts. The types of signs that the most simple and fundamental such as, icons, indexes, and symbol are based on the relation between a representative and its object. This occurs in Basaha Isifu in the people of Kosundano Village where there are various objects, where these objects have a relationship with their representatives. Thus, Basaha Isifu has a number of meanings and has become an icon for the people of Kosundano Village by looking at objects related to their representations so that they can be understood by the wider community, especially the younger generation. The analysis of the symbolic meaning content of each object used in Basaha Isifu in the people of Kosundano Village is as follows.

For this reason, the researcher sees that has becomes an icon in the community of Kosundano Village in the middle of the month of Sha'ban is Basaha Isifu. In this Basaha Isifu tradition, there are a number of traditional culinary delights typical of the Muna people, especially the people of Kosundano Village.

The indexes lie in the sincerity of the organizers, staff, and the local community in carrying out Basaha Isifu. This is based on their understanding that if they carry out this tradition with full sincerity, the guarantee is Heaven. This kind of thing in Islam is known as Ikhsan. Ikhsan is faith in something that is not visible but has absolute truth.

Symbols in Basaha Isifu lie in objects such as the burning of incense, Al-Quran recitation, recitation for Haroa, Greetings, recitation of Isifu water, Pitaraa, Kampanaha, which are all used during the implementation of Basaha Isifu. Each object used has a symbolic meaning that is well understood by the people of Kosundano Village so that it is still maintained today.

\section{CLOSING}

In Basaha Isifu there are several objects that must be prepared, namely, incense, Al Quran, Haroa, Pitaraa, Kampanaha, and
Water for Sara's Servants, isifu water. The implementation process starts with incense burning, reading the Koran, reading Haroa, Greetings, Sarah employees reciting some prayers to water, and eating together. The symbolic meaning in the implementation of the Basaha Isifu lies in each object used and the implementation process. Suggestions from this research for the people of Kosundano district as owners of the tradition, especially the young people, need to improve their understanding and preserve the tradition of Basaha Isifu. It is hoped that all people of Kosundano Village will always maintain the tradition of basaha Isifu as an asset of the local culture of the local community. This is done to minimize the occurrence of tradition shrinkage, for the younger generation, especially as a sustainability of Basaha Isifu so that they will know the symbolic meaning contained in this tradition in the hope that it will not be eroded by global developments in this millennial era.

\section{ACKNOWLEDGEMENT}

The writers would like to thank for all the support given during the writing process of this article, especially the Department of Oral Traditions, Faculty of Humanities, University of Halu Oleo who is dedicated to providing feedback and support for our project entitled "Symbolic Meaning Of Isifu Basis Rituals: The Tradition Of The Muna Society Against Nisfu Sya'ban Night In Muna District" and friends from PGRI Banyuwangi University who gave suggestions and input in the publication and improvement of this article.

\section{REFERENCES}

Asad, M. dkk. 2012.“. Nilai-nilai Keagamaan dalam Petuah Bijak, Puisi dan Peribahasa se Kawasan Timur Indonesia. Laporan Penelitian Balai Penelitian dan Pengembangan Agama Makassar. Bidang Lektur dan Khazanah Keagamaan.

Budiman, Kris. 2011. Semiotika Visual. Yogyakarta: Jalasutra

Hoed, BH 2008. Komunikasi Lisan Sebagai Dasar Tradisi lisan (Dalam Metodologi Kajian Tradisi Lisan). Pudentia (editor). Jakarta:ATL. 
Little, John, Stepen W., adn Karen A. Foss. 2009. Teori Komunikasi. Jakarta: Salemba Humanika.

Maleong, 2001. Metode Penelitian Kualitatif. Bandung: PT Remaja Posdakarya.

Muslim, A. 2016. Artikulasi Religi SajakSajak Basudara di Maluku. Al-Qalam, 19(2), 221-230.

Muslim, A. 2016. Kitorang Samua Basudara: Bijak Bestari di Bilik Harmoni. Harmoni, 15(2), 109-122.

Muslim, A. 2016. Religious and Cultural Harmonies In The Art Of Masamper. Analisa: Journal of Social Science and Religion, 1(2), 259-274.

Muslim, A., Idham, I., \& Subair, M. 2019. Iko Iko Siala Tangang (Tracing Moderatism of Religious Concept From the Oral Traditions of Bajau). In International Conference on Religion and Education.

Pudentia dan Efendi. 1996. Sekitar Penelitian Tradisi Lisan. Warta ATL. Edisi 11/ maret.
Roni, Edi Muhammad. 2018. Tradisi Ruwahan Dan Interaksi Sosial Masyarakat Dusun Bulus IKecamatan Pakem Kabupaten Sleman Yogyakarta. Yogyakarta: Skripsi FISHUM. UIN Suka. Tidak Dierbitkan.

Setiadi E. M dkk (2006) Ilmu Sosial Budaya Dasar. Kencana Prenadamedia Group Rawamangun : Jakarta

Sibarani, Robert. 2012. Kearifan Lokan Hakikat Peranan Metode Tradisi Lisan.Jakarta:ATL. Sudibyo, Lies, dkk. 2013. Ilmu Sosial Budaya Dasar. Yogyakarta: ANDI

Subair, M. 2017. Internalizing Kalosara's Value In A Traditional Dance 'Lulo'in The City Of Kendari, Southeast Sulawesi. Analisa: Journal of Social Science and Religion, 2(2), 198-213.

Sumaatmadja, Nursadi. 1998. Pengantar Studi Sosial. Jakarta: Alumni.

Suraya, Rahmat Sewa. 2014. Tradisi haroa pada etnik muna: Fenomena budaya dalam kehidupan BerAgama di era global. FIB Unifersitas Halu Ole. dalam Jurnal Kajian Budaya, Vol.10.No.20. Juli 2014. 
